\title{
PEMBELAJARAN LINGKARAN BERBANTUAN PERMASALAHAN MATEMATIKA REALISTIK UNTUK MENINGKATKAN KEMAMPUAN PEMECAHAN MASALAH SISWA
}

\author{
Ni Made Dwijayani \\ STIKOM Bali \\ E-mail: dwijayani911@gmail.com
}

\begin{abstract}
The purpose of this research was to develope mathematics instructional materials with ICARE model which were valid, practical, and effective. The instructional materials which were developed in this study consisted of mathematics worksheet. Data were collected by using observation sheet of instructional materials implementation, student's and teacher's response questionnaire, and problem solving test. The collected data analyzed descriptively. The result of this research showed that the developed mathematics instructional materials are categorized "very high" in validity. Based on the results of try out which were conducted, it was obtained that the instructional materials had fulfilled the practicality aspect. It could be seen from: 1) the instructional implementation on limited try out belonged to practical and instructional implementation on the first and the second field try out belonged to very practical; 2) the use of developed mathematics instructional materials which were observed from student's response belonged to practical; and 3) teacher's response towarded the use of mathematics instructional materials belonged to very practical in category. The instructional materials had fulfilled the effectiveness aspects which were seen from: 1) the problem solving skills of students on the first and the second field try out were good in category (had exceeded the standard minimal score). The characteristics of the learning using the developed mathematics instructional materials were: 1) the learning began by introducing students real phenomena and problem in daily life related to the material; 2) giving the students a freedom in giving opinions and discussions; 3) generating social interaction and self-confidence of students, 4) giving the students the learning experience in using GeoGebra; and 5) giving opportunities for students to think about alternative solutions in solving problems.
\end{abstract}

Keywords: ICARE, mathematics, problem, realistic, solving

\section{PENDAHULUAN}

Para guru matematika mempunyai cara yang berbeda-beda dalam mengajarkan siswa untuk memecahkan masalah. Dalam pembelajaran matematika para guru biasanya memberikan contoh-contoh permasalahan matematika dan mengarahkan siswa untuk menentukan bagaimana cara penyelesainnya. Hal tersebut tentunya membuat siswa menjadi kurang kreatif karena siswa cenderung tidak menggunakan caranya sendiri untuk mencari solusinya. Jika hal ini tetap berlangsung di dalam pembelajaran, tentunya hal ini dapat menurunkan kreatifitas siswa untuk berusaha berpikir secara mandiri untuk mencari cara penyelesainya di luar contoh yang diberikan oleh guru.
Parabawanto (2009) menyebutkan bahwa siswa harus dilatih secara rutin untuk menyelesaikan masalah matematika tingkat tinggi karena masalah matematika tersebut akan memberikan kesempatan yang luas bagi siswa untuk mengeksplorasi kemampuan matematikanya. Dengan diberikanya pembelajaran yang saling mengaitkan antara materi di kelas dengan permasalahan sehari-hari tentunya siswa akan mampu melihat kebermanfaatan matematika dalam kehidupan sehari-hari mereka (Prabawanto, 2009).

Pemecahan masalah secara sederhana merupakan proses mengolah masalah yang diterima sebagai tantangan untuk dipecahkan. Polya mendefinisikan pemecahan masalah 
sebagai usaha mencari jalan keluar dari suatu kesulitan, mencapai suatu tujuan yang tidak dengan segera dapat dicapai. Pemecahan masalah melibatkan proses berpikir dan melibatkan penuh usaha. Banyak faktor yang mempengaruhi keberhasilan individu dalam memecahkan masalah matematika. salah satunya adalah keterampilan siswa dalam pemecahan masalah.

Dalam pembelajaran matematika, terdapat berbagai jenis strategi yang dilakukan untuk meningkatkan keberhasilan proses pembelajaran di kelas. Kemampuan pemecahan masalah merupakan salah satu indikator yang menentukan keberhasilan pembelajaran di kelas. Salah satu strategi yang dapat memberikan pengaruh positif terhadap kemampuan pemecahan masalah siswa adalah model pembelajaran ICARE. Model pembelajaran ICARE adalah model pembelajaran yang terdiri dari lima tahapan yaitu Introduction, Connection, Application, Reflection, dan Extension. Introduction atau tahap pendahuluan merupakan tahap dimana guru memotivasi siswa agar siap dan lebih fokus dalam mengikuti pelajaran, mengaitkan permasalahan sehari-hari dengan materi yang akan disampaikan serta menyampaikan tujuan pembelajaran, connection yaitu tahap dimana guru berusaha menghubungkan bahan ajar yang baru dengan sesuatu yang sudah dikenal siswa dari pembelajaran atau pengalaman sebelumnya, application merupakan tahapan yang memberikan kesempatan siswa untuk mempraktikkan dan menerapkan pengetahuan serta kecakapan tersebut, reflection merupakan tahapan untuk merefleksi pembelajaran yang sudah didapatkan, dan extension adalah tahapan untuk menambah penguasaan pemahaman materi di luar jam pelajaran yang dapat dilakukan dengan memberikan tugas rumah. Berdasarkan tahapan tahapan pembelajaran yang terdapat pada model pembelajaran ICARE tentunya setiap tahapnya sangat berpengaruh positif terhadap kemampuan pemecahan masalah siswa.

$\begin{array}{llr}\text { Selain dari segi } & \text { strategi } \\ \text { pembelajaranya, } & \text { yang } & \text { sangat }\end{array}$ berpengaruh terhadap kemampuan pemecahan masalah adalah masalah itu sendiri. Salah satu masalah yang kiranya mampu untuk memotivasi siswa untuk meningkatkan kemampuan pemecahan masalah matematikanya adalah masalah matematika yang realistik. Masalah yang realistik adalah masalah yang dikaitkan dengan dunia nyata yang biasa diakrabi siswa atau masalah yang melibatkan situasi sehingga siswa dapat membayangkan secara konkrit masalah tersebut dalam pikirannya. Menurut Corte, et al (2006) fungsi masalah matematika realistik adalah (1) aplikasi, yaitu untuk mempraktekkan apa yang mereka pelajari di sekolah ke dalam situasi sehari-hari, (2) motivasi, yaitu masalah cerita dapat juga digunakan untuk mendorong siswa bahwa secara real mereka perlu matematika, untuk hidup dalam dunia real, (3) pemancing pikiran, yaitu untuk latihan siswa berpikir kreatif dan mengembangkan keterampilan heuristik mereka dan kemampuan pemecahan masalah, dan (4) keterampilan formasi konsep yaitu untuk mengembangkan konsep dan ketrampilan matematika. Selain fungsi di atas, Menurut NCTM (dalam Prabawanto, 2009) masalah realistik merupakan salah alat yang dapat digunakan untuk menciptakan sebuah koneksi di pemikiran siswa antara konsep matematika yang satu dengan yang lainnya. Secara langsung saat siswa mencoba untuk memahami 
informasi dari permasalahan realistik yang diberikan, secara tidak sadar terjalin koneksi-koneksi dalam otak untuk memproses kaitan-kaitan antara konsep matematika yang sudah diketahui siswa.

Berdasarkan hal tersebut masalah matematika realistik dalam belajar matematika memiliki peranan yang penting yaitu agar anak dapat melihat manfaat matematika dalam kehidupan nyata dan dalam bidang yang lain dan mengembangkan penalaran siswa serta dapat digunakan sebagai sumber inspirasi pembentukan dan pengkonstruksian konsep-konsep matematika atau pengembangan konsep-konsep matematika. Namun sesuai dengan kenyataan di kelas apabila siswa diberikan soal cerita matematika, siswa cenderung kesulitan untuk menyelesaikannya. Hal ini dikarenakan pemikiran awal siswa yang selalu beranggapan soal matematika cerita itu sangat susah dan terkadang siswa mudah untuk menyerah dan tidak mau berusaha untuk memecahkannya. Oleh sebab itu untuk memotivasi siswa agar lebih tertarik dengan masalah yang diberikan soal matematika cerita yang diberikan sebisa mungkin realistik dan dapat dibayangkan oleh siswa. Karena jika siswa sudah mampu membayangkan dan berimajinasi tentang permasalahan tersebut, maka akan muncul rasa ingin tahu dan penasaran untuk mencari solusi dari permasalahan yang diberikan. Apabila siswa diberikan permasalahan realistik tanpa diberikan kesempatan untuk menyelesaikan permasalahan tersebut, tentunya tidak akan berdampak besar terhadap kemampuan pemecahan masalah. Oleh sebab itu pembelajaran yang diberikan haruslah memberikan kesempatan yang lebih luas kepada siswa untuk mengolah informasi, menganalisis dan mecari sendiri solusinya dari informasi-informasi yang sudah dukumpulkan. Melihat begitu pentingya peran masalah realistik dalam pembelajaran, maka dalam penerapan model pembelajaran ICARE dibarengi dengan diberikanya permasalahan realistik kepada siswa agar dapat meningkatkan kemampuan pemecahan masalah. Hubungan antara model ICARE, kemampuan pemecahan masalah dan LAS yang dikembangkan dapat dilihat pada Gambar 1.

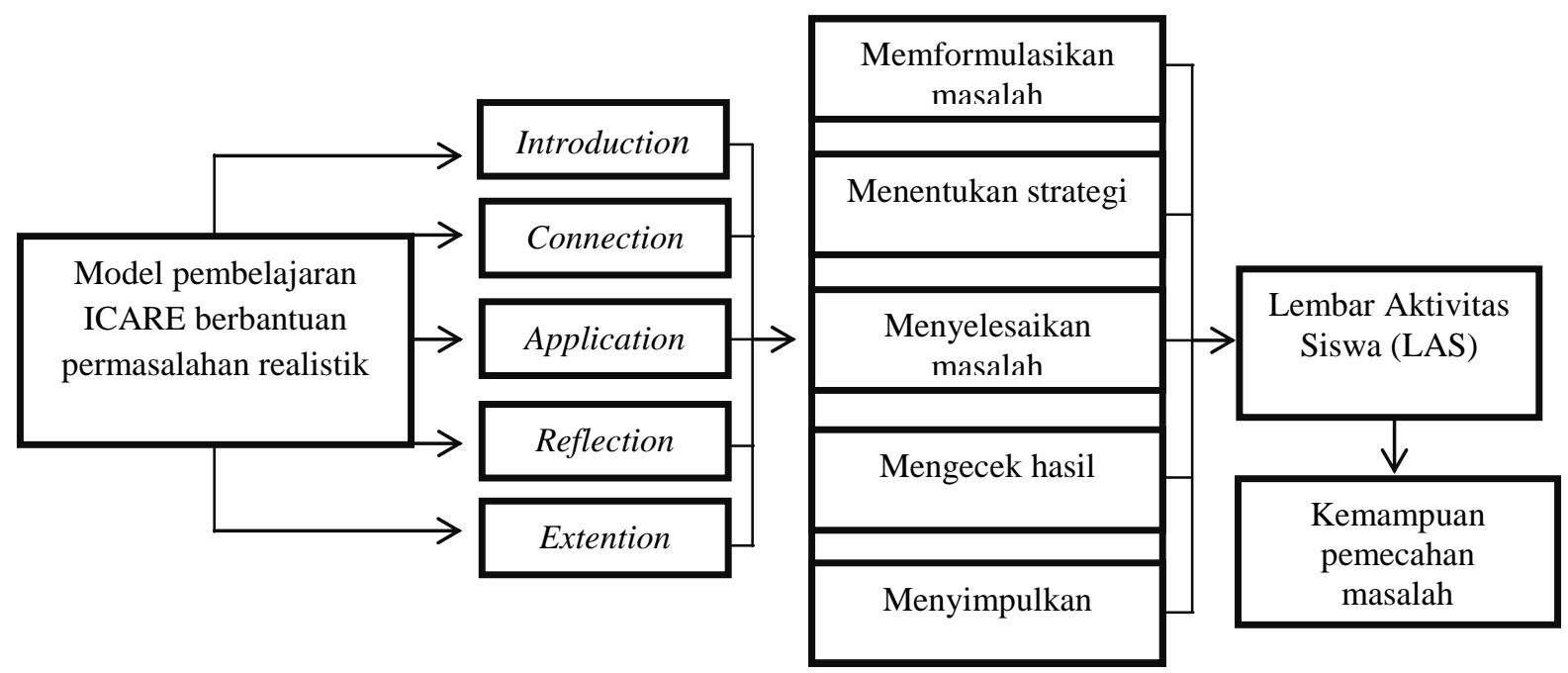

Gambar 1. Hubungan antara model ICARE, kemampuan pemecahan masalah dan LAS 


\section{METODE PENELITIAN}

\begin{tabular}{llr}
\multicolumn{2}{c}{ Penelitian ini } & merupakan \\
penelitian desain yang & $\begin{array}{r}\text { teorinya } \\
\text { penelitian }\end{array}$ \\
mengacu pada & Plomp. \\
pengembangan & oleh & Plomp
\end{tabular}

Berdasarkan teori tersebut, ada tiga fase dalam penelitian desain, yang meliputi: preliminary research, prototyping, dan assessment (Plomp, 2013). Tujuan dari penelitian ini untuk mengembangkan sebuah produk yaitu LAS lingkaran untuk kelas XI. Media yang didesain dalam penelitian ini menggunakan software GeoGebra yang beorientasi pada model ICARE. Selain media, dalam penelitian ini juga akan disusun perangkat pembelajaran pendukung berupa Rencana Pelaksanaan Pembelajaran (RPP) yang sesuai dengan topik pada media. LAS yang didesain ditentukan kualitasnya berdasarkan tiga aspek yaitu validitas, kepraktisan dan efektivitas.

Peserta didik berperan dalam hal perolehan data tentang kepraktisan dan keefektifan perangkat pembelajaran berupa LAS. Peserta didik yang dimaksud adalah peserta didik kelas XI SMA Negeri 1 Kuta Utara khususnya kelas XI IPA 1, XI IPA 2, dan XI IPA 5. Pemilihan kelas XI sebagai subjek penelitian berdasarkan atas beberapa pertimbangan yang pada dasarnya mendukung keterwujudan perangkat pembelajaran yang dikembangkan yaitu karakteristik peserta didik yang heterogen, kemampuan kelas yang setara, serta menerapkan kurikulum 2013. Selain itu, pemilihan subjek penelitian karena peserta didik yang belum mengkonstruksi sebuah konsep dengan menggunakan LAS matematika namun hanya menggunakan LKS yang sudah disediakan oleh penerbit. Guru berperan dalam hal perolehan data tentang kepraktisan perangkat pembelajaran keseluruhan. Guru yang dimaksud di sini adalah guru matematika kelas XI SMA Negeri 1 Kuta Utara.

Pada fase preliminary research difokuskan pada menganalisis situasi, kebutuhan dan permasalahan yang terjadi pada pembelajaran matematika di sekolah. Kegiatan yang dilaksanakan pada fase ini yaitu; 1) melaksanakan observasi pada proses pembelajaran, 2) melaksanakan wawancara kepada guru matematika kelas XI dan beberapa peserta didik kelas XI, 3) melaksanakan analisis dokumen yakni dokumen mengenai hasil belajar matematika peserta didik kelas XI dan meninjau media serta perangkat pembelajaran yang digunakan dalam pembelajaran matematika di kelas. Selain melakukan studi lapangan, dalam fase ini juga dilakukan studi pustaka, dan meninjau contoh-contoh LAS matematika yang relevan sebagai bahan pertimbangan dalam membuat LAS. Dari hasil identifikasi terhadap pelaksanaan pembelajaran maupun media serta perangkat pendukung pembelajaran matematika, selanjutnya kajian-kajian yang ditemukan digunakan untuk merancang LAS dan perangkat pendukungnya berupa RPP. Selain itu juga disusun draft awal LAS yang berorientasi pada model ICARE. Draf awal ini disebut prototipe I.

Pada tahap prototyping dilakukan penyusunan desain suatu LAS lingkaran dan perangkat pembelajaran yang mendukung. Kemudian media yang sudah disusun dilihat kualitasnya. Halhal yang dilakukan adalah menguji validitas perangkat pembelajaran yang masih berupa prototipe I oleh dua orang pakar (validator). Berdasarkan hasil uji validasi ini kemudian dilakukan revisi sehingga diperoleh perangkat pembelajaran dalam bentuk prototipe II yang berkualitas valid untuk kemudian 
dilakukan uji coba lapangan. Uji coba lapangan dilakukan untuk mengetahui kepraktisan dan efektivitas perangkat pembelajaran yang dikembangkan. Uji coba pertama yang dilakukan adalah uji coba terbatas. Dalam uji coba terbatas, perangkat diujicobakan pada 12 siswa kelas XI IPA 1 dan pembelajaran dilakukan dalam dua kali pertemuan dengan topik pembelajaran adalah persamaan umum lingkaran. Fokus dari uji coba ini adalah untuk mendapatkan gambaran keterlaksanaan pembelajaran matematika dengan menggunakan LAS ICARE. Pengamatan dilakukan selama berlangsungnya kegiatan pembelajaran dengan melibatkan guru mata pelajaran matematika kelas VIII dan peneliti. Kritik atau saran yang diperoleh pada tahap ini dijadikan bahan revisi prototipe II sehingga terbentuklah prototipe III.

Selanjutnya prototipe III yang telah disusun kemudian diujicobakan. Uji coba selanjutnya disebut uji coba lapangan I yang dilaksanakan pada satu kelas yaitu kelas XI IPA 2. Fokus dari uji coba ini adalah meningkatkan kualitas produk atau mendapatkan karakteristik media pembelajaran yang dikembangkan yang praktis dan efektif. Pengamatan (observasi) dilakukan selama berlangsungnya kegiatan pembelajaran untuk melihat keterlaksananan penggunaan perangkat pembelajaran dengan melibatkan guru matematika kelas XI dan peneliti. Setelah uji coba, siswa dan guru memberikan respons mengenai perangkat pembelajaran yang dikembangkan tersebut dengan menggunakan angket respons siswa dan angket respons guru. Selain itu, siswa juga diberikan tes kemampuan pemecahan masalah. Hasil dari pemberian angket dan tes tersebut digunakan sebagai bahan untuk merevisi prototipe III. Hasil revisi prototipe III disebut prototipe IV.

Pada fase assessment

dilaksanakan uji coba lapangan II dengan melibatkan siswa kelas XI IPA 5. Pengamatan (observasi) dilakukan selama berlangsungnya kegiatan pembelajaran untuk melihat keterlaksananan penggunaan perangkat pembelajaran dengan melibatkan guru kelas dan peneliti. Setelah pelaksanaan pembelajaran siswa kembali melakukan tes pemecahan masalah dan memberikan respons mengenai perangkat pembelajaran yang dikembangkan tersebut. Guru kelas juga memberikan respons mengenai perangkat pembelajaran tersebut. Hasil respons siswa dan guru tersebut digunakan sebagai bahan revisi, sehingga diperoleh karakteristik media pembelajaran yang berkualitas praktis, dan efektif (produk final). Lebih jelasnya proses pengembangan produk atau prototipe ditunjukkan pada Gambar 2. Data yang telah terkumpul kemudian diolah secara deskriptif. Perangkat pembelajaran dalam penelitian ini minimal harus mencapai kategori valid, praktis, dan efektif.

Perangkat yang dikembangkan akan ditentukan validitasnya berdasarkan kriteria seperti yang ditunjukkan pada Tabel 1 di bawah ini. 
ISSN 2089-8703 (Print) Vol. 7, No. 1 (2018)

ISSN 2442-5419 (Online)

Tabel 1. Kriteria Kevalidan Perangkat Pembelajaran

\begin{tabular}{|c|c|}
\hline Skor & Kriteria \\
\hline $3,5 \leq V r \leq 4,0$ & Sangat Valid \\
\hline $2,5 \leq V r<3,5$ & Valid \\
\hline $1,5 \leq V r<2,5$ & Tidak Valid \\
\hline $1,00 \leq V r<1,5$ & Sangat Tidak Valid \\
\hline
\end{tabular}

Kategori valid diberikan apabila rata-rata skor kedua validator minimal berada pada rentang $2,5 \leq V<3,5$ dan validasi tes pemecahan masalah minimal 0,7.

Perangkat pembelajaran dalam penelitian ini minimal harus mencapai kategori tinggi yaitu berada pada rentang skor $2,5 \leq \operatorname{Pr}<3,5$ untuk bisa dinyatakan praktis dan dapat digunakan dalam pembelajaran di kelas. Kriteria tingkat kepraktisan perangkat pembelajaran yang dikembangkan disesuaian dengan tabel 2 berikut.

Tabel 2. Kriteria Kepraktisan Perangkat Pembelajaran

\begin{tabular}{|c|c|}
\hline Skor & Kriteria \\
\hline $3,5 \leq \operatorname{Pr} \leq 4,0$ & Sangat Tinggi (Sangat Praktis) \\
\hline $2,5 \leq \operatorname{Pr}<3,5$ & Tinggi (Praktis) \\
\hline $1,5 \leq \operatorname{Pr}<2,5$ & Cukup (Kurang Praktis) \\
\hline $1,00 \leq \operatorname{Pr}<1,5$ & Kurang (Sangat Tidak Praktis) \\
\hline
\end{tabular}

Data mengenai kemampuan pemecahan masalah matematika siswa dapat diperoleh melalui tes kemampuan pemecahan masalah matematika yang dilakukan pada tahap akhir eksperimen. Tes yang diberikan berupa soal uraian karena dalam menjawab soal-soal uraian siswa dituntut untuk mampu mengembangkan pengetahuan dan keterampilan yang dimiliki. Akan tetapi, soal uraian memiliki kelemahan pada pemeriksaan jawaban yang cenderung bersifat subyektif. Untuk mengantisipasi hal tersebut, dalam melakukan penskoran jawaban dari siswa terlebih dahulu dibuat rubrik penskoran.

Tes pemecahan masalah matematika diperiksa dengan menggunakan rubrik penskoran analitik artinya rubrik penskoran yang digunakan disesuaikan dengan permasalahan yang diberikan dalam tes. Hal ini mengingat tingkat kesulitan, dan variasi setiap masalah berbeda-beda sehingga rubrik yang digunakan juga berbeda-beda. Skor yang diberikan disesuaikan dengan tahapan-tahapan pemecahan masalah matematika seperti pada Tabel 3 berikut. 
ISSN 2089-8703 (Print) Vol. 7, No. 1 (2018)

ISSN 2442-5419 (Online)

Tabel 3. Indikator Penskoran Tes Pemecahan Masalah Matematika

\begin{tabular}{|c|c|c|}
\hline $\begin{array}{l}\text { Tahapan } \\
\text { Pemecahan } \\
\text { Masalah }\end{array}$ & Indikator NCTM & Indikator Penskoran \\
\hline $\begin{array}{l}\text { Memahami } \\
\text { masalah }\end{array}$ & $\begin{array}{l}\text { Memformulasikan } \\
\text { masalah. } \\
\text { (Formulate problems) }\end{array}$ & \begin{tabular}{ll} 
- & \multicolumn{2}{c}{ Mengidentifikasi } \\
informasi yang dapat & digunakan \\
menyelesaiakan & untuk \\
permasalahan &
\end{tabular} \\
\hline $\begin{array}{l}\text { Membuat rencana } \\
\text { penyelesaian } \\
\text { masalah }\end{array}$ & $\begin{array}{l}\begin{array}{l}\text { Menentukan } \\
\text { strategi berbagai } \\
\text { menyelesaikan }\end{array} \\
\text { permasalahan. } \\
\text { (Apply a variety of } \\
\text { strategies to solve } \\
\text { problems) }\end{array}$ & $\begin{array}{l}\text { - } \text { Menyatakan } \\
\text { informasi yang } \\
\text { didapatkan dalam } \\
\text { kalimat matematika. } \\
\text { - Menggambarkan } \\
\text { permasalahan dalam } \\
\text { bentuk gambar, grafik, } \\
\text { dan lain-lain. } \\
\text { Membuat langkah- } \\
\text { langkah penyelesaian. }\end{array}$ \\
\hline $\begin{array}{l}\text { Menyelesaikan } \\
\text { masalah }\end{array}$ & $\begin{array}{l}\text { Menyelesaikan masalah. } \\
\text { (Solve Problems) }\end{array}$ & $\begin{array}{l}\text { - Melakukan } \\
\text { perhitungan yang } \\
\text { sistematis sesuai rencana } \\
\text { yang telah disusun. }\end{array}$ \\
\hline $\begin{array}{l}\text { Memeriksa } \\
\text { kembali }\end{array}$ & $\begin{array}{l}\text { Mengecek dan } \\
\text { menginterpretasikan hasil } \\
\text { yang telah diperoleh. } \\
\text { (Verify and Interpret } \\
\text { results) }\end{array}$ & 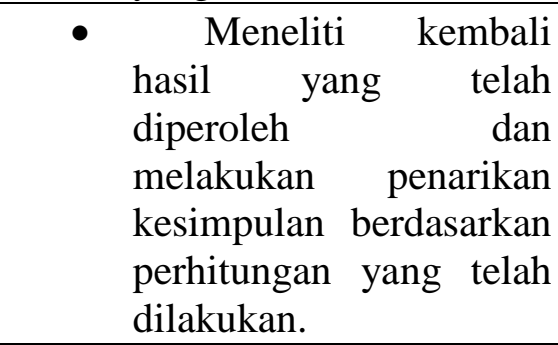 \\
\hline
\end{tabular}

Sedangkan kriteria penggolongan kemampuan pemecahan masalah siswa disesuaikan dengan Tabel 4 di bawah ini.

Tabel 4. Kriteria Penggolongan Kemampuan Pemecahan Masalah Siswa

\begin{tabular}{|c|c|}
\hline Rentang Skor & Kategori \\
\hline $\bar{X} \geq 80$ & Sangat tinggi \\
\hline $60 \leq \bar{X}<80$ & Tinggi \\
\hline $40 \leq \bar{X}<60$ & Cukup \\
\hline
\end{tabular}

Alur kegiatan pengembangan perangkat pembelajaran ini dapat dirangkum dalam bentuk bagan seperti yang ditunjukkan pada Gambar 2. 


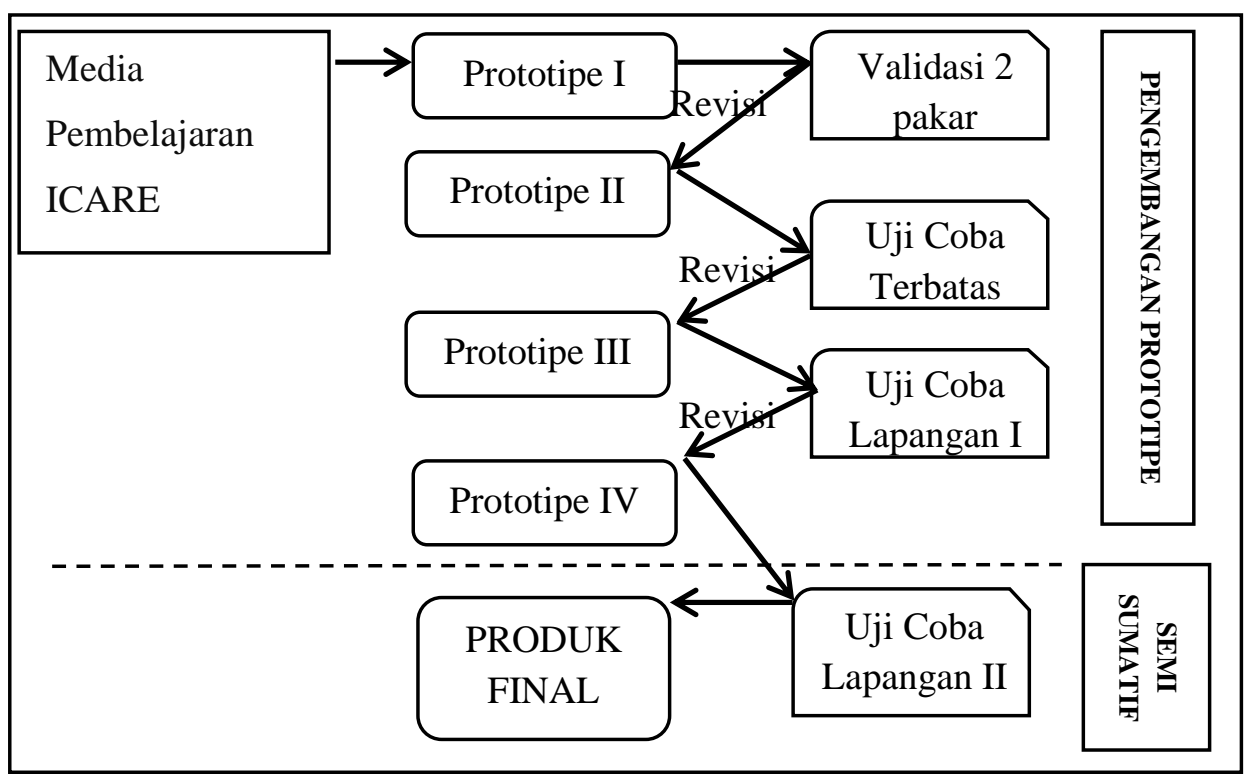

Gambar 2. Alur pengembangan perangkat pembelajaran

\section{HASIL DAN PEMBAHASAN}

Perangkat pembelajaran yang dikembangkan pada peneitian ini berupa lembar aktivitas siswa (LAS). Produk yang dihasilkan berbeda dengan LKS cetak yang digunakan selama ini di sekolah. Perbedaannya yaitu, penggunaan LAS tidak hanya menuntut siswa untuk mengisi bagian kosong ( fill in the blank ) tetapi juga membantu siswa untuk menemukan kembali sebuah konsep lingkaran. Hal tersebut didukung juga dengan penggunaan media pembelajaran yang berbasis Geogebra. Berdasarkan hasil penelitian desain yang telah dilaksanakan, prosedur pengembangan produk berupa LAS ICARE pada prinsipnya sama dengan prosedur pengembangan menurut Plomp.

Pada tahap preliminary research ditemukan bahwa 1) peserta didik belum memahami cara menyusun persamaan lingkaran dengan baik, 2) peserta didik masih mengalami kesulitan dalam menemukan kembali sebuah konsep, 3) peserta didik hanya mampu menyelesaikan soal-soal rutin yang diberikan oleh guru, 4) kemampuan pemecahan masalah peserta didik masih rendah, dan 5) peserta didik tidak pernah belajar menggunakan LAS. Dari hasil identifikasi tersebut, selanjutnya dirancang LAS dan instrumeninstrumen penelitian. Pada tahap prototyping perangkat pembelajaran yang telah disusun dilihat kualitasnya. Hal-hal yang dilakukan adalah menguji validitas LAS yang masih berupa prototipe I oleh dua orang pakar (validator). Tidak hanya menilai validitas LAS, validator juga menilai validitas instrumen yang akan digunakan pada kegiatan uji coba.

Pada Tabel 5 berikut disajikan rangkuman dari saran/komentar dari validator terhadap instrumen yang dikembangkan. 
Tabel 5. Rangkuman Saran dari Validator

\begin{tabular}{|c|l|l|}
\hline \multirow{2}{*}{ No } & \multicolumn{2}{|c|}{ SARAN/KOMENTAR VALIDATOR } \\
\cline { 2 - 3 } & \multicolumn{1}{|c|}{ Validator I } & \multicolumn{1}{c|}{ Validator II } \\
\hline 1 & $\begin{array}{l}\text { Pembuatan simpulan terlalu memaksa } \\
\text { peserta didik mengikuti jalan pikiran } \\
\text { guru dan kurang memberikan } \\
\text { kesempatan untuk berkreativitas pada } \\
\text { peserta didik. }\end{array}$ & $\begin{array}{l}\text { Bahasa yang digunakan masih banyak } \\
\text { yang ambigu dan belum baku. }\end{array}$ \\
\hline 2 & $\begin{array}{l}\text { Tahap ketiga untuk memperoleh } \\
\text { simpulan diganti dengan memberikan } \\
\text { pertanyaan kepada peserta didik } \\
\text { seperti kolom di atas. }\end{array}$ & $\begin{array}{l}\text { Lebih baik meminta siswa untuk } \\
\text { menggambarkan lingkaran pada media } \\
\text { yang mendukung LAS untuk } \\
\text { memahami persamaan lingkaran di } \\
\text { pusat (a,b) }\end{array}$ \\
\hline 3 & Perbaiki media pendukung LAS & - \\
\hline
\end{tabular}

Berdasarkan hasil uji validasi terhadap LAS, kemudian dilakukan revisi sehingga diperoleh perangkat pembelajaran dalam bentuk prototipe II dengan kriteria perangkat pembelajaran yang dikembangkan adalah valid. Begitu juga instrumen untuk mengukur kepraktisan dan efektivitas seperti angket respons siswa dan guru, lembar pengamatan keterlaksanaan, dan tes pemecahan masalah dikategorikan sangat valid. Setelah diperoleh perangkat pembelajaran dalam bentuk prototipe II, kemudian dilakukan uji coba lapangan untuk mengetahui keterlaksanaan, kepraktisan, dan efektivitas perangkat pembelajaran yang dikembangkan.

Uji coba pertama yang dilakukan adalah uji coba terbatas. Dalam uji coba terbatas, perangkat diujicobakan pada 12 siswa kelas XI IPA 1 dan pembelajaran dilakukan dalam dua kali pertemuan dengan topik pembelajaran adalah persamaan umum lingkaran. Pada uji coba terbatas, rata-rata skor pengamatan keterlaksanaan yang diperoleh selama melaksanakan pembelajaran dengan menggunakan perangkat pembelajaran matematika yang disusun adalah 3,21. Berdasarkan kriteria kepraktisan dapat dikatakan bahwa LAS yang digunakan dalam pembelajaran tergolong Praktis karena rata-ratanya berada pada interval $2,5 \leq P<3,5$. Pada saat uji coba terbatas, terdapat beberapa kendala yang dihadapi diantaranya adalah bahasa atau istilah di LAS yang sulit dipahami oleh peserta didik. Selama pelaksanaan uji coba terbatas, diperoleh beberapa kekurangan pada perangkat pembelajaran yang diduga dapat mengganggu keterlaksanaan pembelajaran pada uji coba selanjutnya. Kekurangan tersebut terletak pada penyajian petunjuk penggunaan LAS. Hasil revisi yang dilakukan pada tahap ini selanjutnya disebut dengan Prototipe III. Setelah diperoleh perangkat pembelajaran dalam bentuk Prototipe III, kemudian dilakukan uji coba lapangan I untuk mengetahui keterlaksanaan, kepraktisan, dan efektivitas perangkat pembelajaran yang dikembangkan.

Dalam uji coba lapangan I, perangkat diujicobakan pada kelas XI IPA 2. Kepraktisan perangkat diukur dari keterlaksanaan pembelajaran dengan menggunakan lembar pengamatan keterlaksanaan serta respons siswa dan guru terhadap perangkat pembelajaran yang 
dikembangkan. Pada uji coba lapangan I, rata-rata skor keterlaksanaan adalah 3,25 di mana tergolong dalam kategori Praktis, rata-rata skor respons siswa adalah 3,06 masuk dalam kategori Praktis, dan rata-rata skor respons guru terhadap perangkat pembelajaran sebesar 3,34 masuk dalam kategori Praktis. Selain kepraktisan, pada uji coba lapangan I juga mengukur efektivitas perangkat pembelajaran. Tes pemecahan masalah yang diperoleh menunjukkan rata-rata skor siswa adalah 81,17. Rata-rata skor tes pemecahan masalah kelas XI lebih dari KKM yaitu 80 yang merupakan kriteria efektivitas untuk pemecahan masalah. Rata-rata skor pemecahan masalah yang lebih dari KKM menunjukkan bahwa perangkat pembelajaran matematika yang dikembangan dapat dikatakan efektif. Selain itu, kemampuan siswa dalam memahami sebuah konsep juga mendukung kemmapuan siswa dalam menyelesaikan masalah matematis. Hal tersebut sejalan dengan penelitian yang dilaksanakan oleh Lestari dan Surya (2017) yang menemukan bahwa pemahaman konsep siswa yang terbiasa menggunakan kemampuan pemecahan masalah realistik lebih baik daripada yang hanya menggunakan metode konvensional. Namun, pada pelaksanaan uji coba lapangan I terdapat pula kekurangan dalam perangkat (prototipe III) yang perlu direvisi, hasil revisi dari prototipe III disebut prototipe IV.

Pada tahap asessment, perangkat pembelajaran dalam bentuk Prototipe III, kemudian dilakukan uji coba lapangan II untuk mengetahui keterlaksanaan, kepraktisan, dan efektivitas perangkat pembelajaran yang dikembangkan. Dalam uji coba lapangan II perangkat diujicobakan pada kelas XI IPA 5. Kepraktisan perangkat diukur dari keterlaksanaan pembelajaran dengan menggunakan LAS yang dikembangkan, respons siswa dan guru terhadap LAS yang dikembangkan. Pada uji coba lapangan II, rata-rata skor keterlaksanaan adalah 3,65 dimana tergolong dalam kategori Sangat Praktis, rata-rata skor respons siswa adalah 3,28 masuk dalam kategori Praktis, dan rata-rata skor respons guru terhadap perangkat pembelajaran sebesar 3,62 masuk dalam kategori Sangat Praktis. Selain kepraktisan, pada uji coba lapangan II juga mengukur efektivitas perangkat pembelajaran. Hasil tes pemecahan masalah yang diperoleh menunjukkan bahwa rata-rata skor pemecahan masalah siswa adalah 82,13. Rata-rata skor pemecahan masalah kelas XI IPA 5 lebih dari KKM yaitu 80 yang merupakan kriteria efektivitas untuk pemecahan masalah.

Dengan adanya peningkatan ratarata skor pemecahan masalah sama dengan atau lebih dari KKM, LAS yang dikembangan dapat dikatakan efektif. Jadi, secara umum pada kegiatan uji coba terbatas, uji coba lapangan I, dan uji coba lapangan II perangkat pembelajaran yang dikembangkan sudah memenuhi kriteria valid, praktis, dan efektif. Berdasarkan kegiatan uji coba dan kajian terhadap teori-teori yang mendukung dapat disimpulkan bahwa terdapat beberapa hal yang menyebabkan LAS yang dikembangkan memenuhi kriteria valid, praktis dan efektif.

LAS yang dikembangkan dapat tergolong valid karena a) LAS yang dikembangkan sudah sesuai dengan tuntutan kurikulum, maksudnya adalah karakteristik kurikulum menjadi salah satu pedoman dalam menyusun LAS yang bertujuan agar apa yang diharapkan dalam kurikulum dapat tercapai apabila pembelajaran menggunakan lembar aktivitas, b) LAS mampu memotivasi peserta didik dalam 
belajar yang dikarenakan lembar aktivitas yang dikembangkan sesuai dengan tingkat perkembangan peserta didik, c) kegiatan pembelajaran terfokus pada peserta didik yang memudahkan peserta didik untuk menemukan kembali sebuah konsep dengan menggunakan bantuan Geogebra. Penggunaan media pembelajaran, seperti Geogebra, selain dapat meningkatkan kemampuan pemecahan masalah siswa juga dapat meminimalkan miskonsepsi pada siswa (Laurens et al, 2017).

Selanjutnya, LAS yang dikembangkan tergolong praktis karena memberikan manfaat kepada guru dan juga peserta didik. Beberapa manfaat yang diberikan adalah a) LAS yang digunakan dapat menumbuhkan antusias peserta didik dalam belajar geometri khususnya lingkaran karena peserta didik diberikan langkah-langkah dalam menemukan kembali sebuah konsep, b) LAS dapat memfasilitasi peserta didik untuk membuat simpulan, c) RPP yang detail dan jelas memberikan kemudahan bagi guru sehingga tidak perlu persiapan yang banyak, d) peserta didik menjadi lebih tahu bahwa matematika tidak hanya rumus, terlebih lagi pada topik lingkaran yang memiliki banyak subtopik, e) peserta didik termotivasi untuk belajar dengan menggunakan LAS karena mereka menganggap lebih praktis mengunakan lembar aktivitas, f) penggunaan bantuan GeoGebra dalam LAS ini memberikan gambaran yang lebih jelas dan memudahkan siswa untuk memahami gambar dan kedudukan lingkaran, dan g) penggunaan bantuan GeoGebra dalam LAS ini memudahkan siswa dalam memecahkan permasalahan yang disajikan dalam kegiatan latihan soal.

Selain itu, secara statsitik nilai rata-rata siswa yang dibelajarkan dengan model pembelajaran ICARE berbantuan permasalahan realistik tergolong dalam kategori tinggi. Hal ini menunjukkan bahwa kemampuan pemecahan masalah matematika siswa yang dibelajarkan dengan model pembelajaran ICARE berbantuan permasalahan matematika realistik menunjukkan hasil yang lebih baik. Hasil tersebut ekuivalen dengan hasil penelitian oleh Maskur (2012). Maskur (2012) menyebutkan bahwa dengan menggunakan uji banding, kelompok yang diajarkan dengan model pembelajaran ICARE menunjukkan rata-rata yang lebih besar dibandingakan dengan kelompok yang dibelajarkan dengan model pembelajaran ekspositori. Dalam hasil penelitianya Maskur (2012) meyebutkan bahwa motivasi siswa yang dibelajarkan dengan model pembelajaran ICARE termasuk dalam kategori sangat baik. Hal tersebut menunjukkan bahwa model pembelajaran ICARE memberikan dampak yang positif terhadap kemampuan matematika siswa terutama kemampuan pemecahan masalah.

Kelebihan dari LAS dengan menggunakan model pembelajaran ICARE yang terdiri dari 5 tahapan yaitu Introduction, Connection, Application, Reflection, dan Extension dijelaskan sebagai berikut. Tahap Introduction adalah tahap dimana para guru atau fasilitator menanamkan pemahaman tentang tujuan dan manfaat dari pembelajaran yang akan diajarkan kepada para peserta. Bagian ini harus berisi penjelasan tujuan pembelajaran dan apa yang akan dicapai selama pelajaran tersebut. Pada tahap ini guru berusaha untuk memotivasi siswa dan membangun antusias siswa untuk mempelajari materi yang akan dibahas.

Tahap selanjutnya yaitu connection. Pada tahap ini guru seting 
pembelajaran agar siswa berusaha untuk menghubungkan bahan ajar yang baru dengan sesuatu yang sudah dikenal siswa dari pembelajaran atau pengalaman sebelumnya. Hal ini dilakukan dengan mengadakan latihan brainstorming yang sederhana untuk memahami apa yang telah diketahui siswa, dengan meminta mereka untuk memberitahukan apa yang mereka ingat dari pembelajaran sebelumnya atau dengan mengembangkan sebuah kegiatan yang dapat dilakukan siswa dan setelah itu siswa dapat diarahkan oleh guru untuk menghubungkan informasi baru.

Selanjutnya yaitu tahap application. Tahap ini adalah tahap yang paling penting pada proses pembelajaran. Setelah peserta memperoleh informasi atau kecakapan baru melalui tahap connection, mereka perlu diberi kesempatan untuk mempraktikkan dan menerapkan pengetahuan serta kecakapan tersebut.

Tahap keempat yaitu tahap reflection. Bagian ini merupakan refleksi dari kegiatan pembelajaran. Siswa berusaha untuk merefleksi apa yang telah mereka kerjakan pada tahap sebelumnya, dan berusaha mengkoreksi kembali jika terdapat kesalahan- kesalahan pada penyelesaian permasalahan yang diberikan. Tugas guru adalah menilai sejauh mana keberhasilan pembelajaran. Kegiatan refleksi atau ringkasan dapat melibatkan diskusi kelompok dimana guru meminta siswa untuk melakukan presentasi atau menjelaskan apa yang telah mereka pelajari. Poin penting untuk diingat dalam refleksi adalah guru perlu menyediakan kesempatan bagi siswa untuk mengungkapkan apa yang telah mereka pelajari.

Terakhir yaitu tahap extension. Kegiatan extension adalah kegiatan dimana guru menyediakan kegiatan yang dapat dilakukan siswa setelah pembelajaran berakhir untuk memperkuat dan memperluas pembelajaran. Kegiatan extension dapat dilakukan dengan meberikan tugas rumah pada siswa.

Hasil dari LAS ICARE ini belum dapat dipublikasikan karena terkait dengan hak cipta dan juga pengembangan media pembelajaran pada penelitian berikutnya yang masih berlangsung. Secara umum, hasil dari LAS ICARE yang berbantuan Geogebra dapat dilihat pada Gambar 3 dan Gambar 4 berikut. 
ISSN 2089-8703 (Print) Vol. 7, No. 1 (2018)

ISSN 2442-5419 (Online)
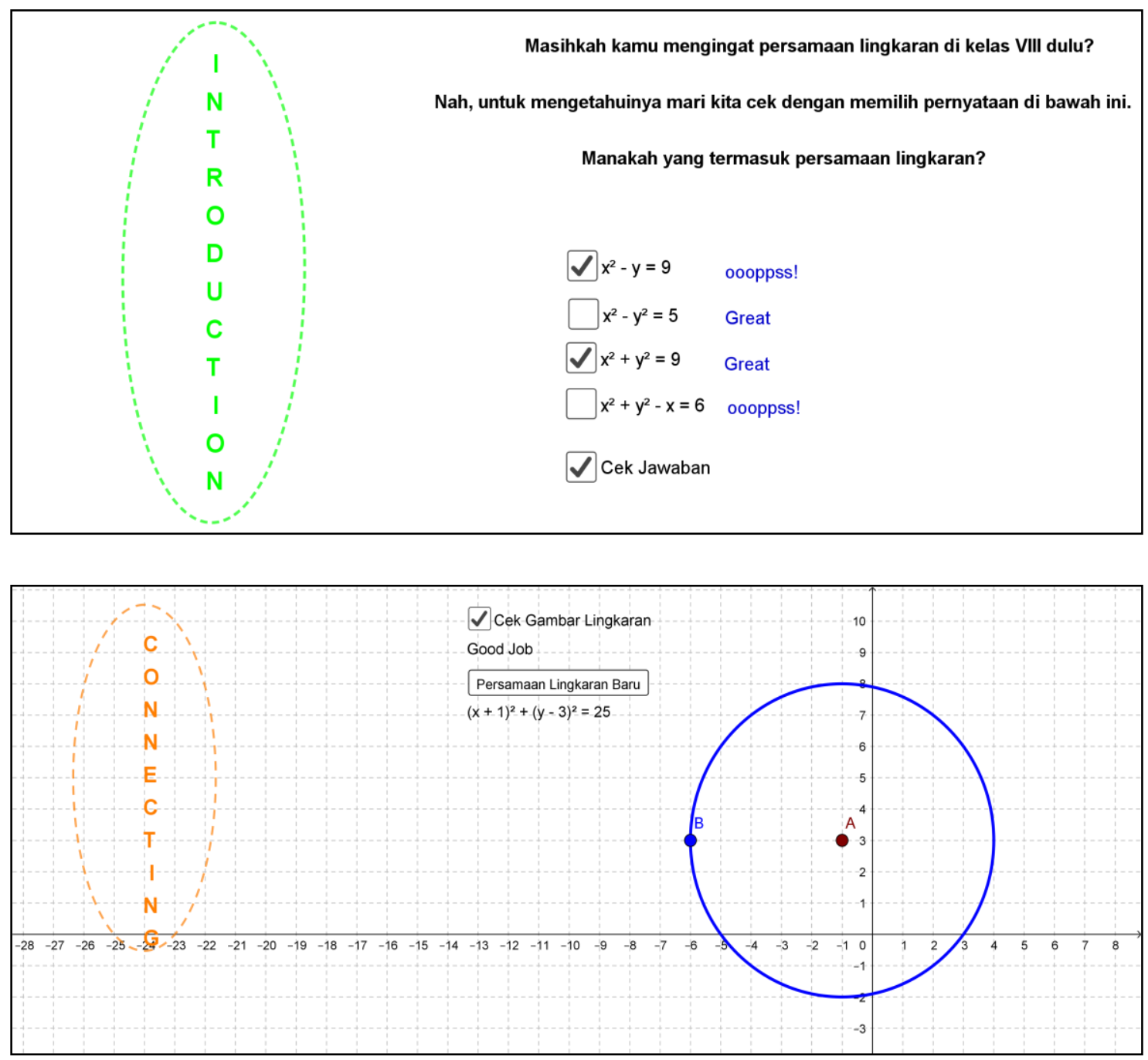

Gambar 3. Tahap Introduction dan Connection dengan menggunakan Geogebra

\section{KESIMPULAN DAN SARAN}

Berdasarkan hasil penelitian dan pembahasan sebagaimana tersebut di atas, dapat disimpulkan bahwa LAS ICARE yang memenuhi kriteria validitas, kepraktisan, dan efektivitas yang diharapkan serta mampu meningkatkan kemampuan pemecahan masalah siswa. Karakteristik atau keistimewaan dari perangkat pembelajaran yang dikembangkan dalam penelitian ini antara lain sebagai berikut: 1) praktis dalam penggunaan; (2) kegiatan pembelajaran mengarahkan siswa untuk terbiasa memecahkan masalah matematika; (3) latihan soal dan masalah-masalah riil yang memberikan kesempatan siswa untuk memikirkan berbagai alternatif solusi dalam pemecahan masalah; dan (4) memberikan variasi dalam pembelajaran.

Bagi peneliti selanjutnya yang ingin mengembangkan pembelajaran matematika yang inovatif dapat menjadikan hasil penelitian ini sebagai pedoman baik dari segi prosedur pengembangan maupun proses untuk melihat kualitas perangkat pembelajaran. Perlu untuk diperhatikan, 
bahwa hasil penelitian ini masih perlu ditindaklanjuti dalam bentuk sosialisasi LAS ICARE kepada guru-guru di SMA sehingga perangkat pembelajaran yang dikembangkan dapat diterima dan digunakan dalam kegiatan pembelajaran di kelas.

\section{DAFTAR PUSTAKA}

Corte, E.D., Depaepe, F. \& Verschaffel, L. 2006. Investigating Social and Individual Aspects in Teachers' Approaches to Mathematical Problem Solving. [Online]. Tersedia: http://math.unipa.it/ grim/21_pr oject/21_charlotte_DeCortePape rEdit2. pdf. [12 Maret 2017].

Laurens, et al. 2017. How Does Realistic Mathematics Education (RME) Improve Students' Mathematics Cognitive Achievement?. EURASIA Journal of Mathematics, Science and Technology Education. Vol. 14, No. 2, Hal. 569 - 578.

Lestari, L. dan Surya, E. 2017. The Effectiveness of Realistic Mathematics Education Approach on Ability of Students' Mathematical Concept Understanding. International Journal of Sciences: Basic and Applied Research (IJSBAR). Vol. 34, No. 1. Hal. 91-100.

Maskur, A. 2012. Pembelajaran Matematika dengan Model ICARE Beracuan Kontruktivisme untuk Meningkatkan Kemampuan Berpikir Kreatif Materi Dimensi Tiga. Journal of Primary Education. Vol. 2, Hal 86-90.
Plomp, T., \& Nieveen, N. 2013. Educational Design Research. Netherlands: Netherlands Institute for Curriculum Development (SLO).

Prabawanto, S. 2009. Pembelajaran Matematika dengan Pendekatan Realistik untuk Meningkatkan Kemampuan Pemecahan Masalah dan Disposisi Matematika Siswa. Disampaikan dalam Acara Workshop Nasional PMRI untuk Dosen S1 Matematika PGSD di Hotel Cipaku Indah Bandung 27-30 Oktober 2009 .http://www.file.upi.edu/ (Diakses pada tanggal 18 Maret 2017) 